\title{
Deconstructing Social Media: An Analysis of Twitter and Facebook Use in the Publishing Industry
}

\author{
Jamie Criswell • Nick Canty
}

Published online: 4 October 2014

(C) The Author(s) 2014. This article is published with open access at Springerlink.com

\begin{abstract}
The article analyses the social media activity around two genre fiction titles published in the UK. The research is focused on the platforms Twitter and Facebook as they are the sites currently most used as marketing tools by the publishing industry. Over 10,000 social media posts were collected and categorised to create a timeline of social media activity for two case studies. The findings were then compared to sales data from Nielsen BookScan to give an understanding to the value of social media marketing in the publishing industry. The findings show that social media is most effective as a marketing platform when there is already an established community, allowing publishers to converse with readers. While social media is less effective at marketing new books written by debut authors with no existing readership, it is none the less an important tool in the marketing plan as it provides a platform to engage with readers around significant events.
\end{abstract}

Keywords Social media - Twitter · Facebook - Publishing industry · Publisher . Books

\section{Introduction}

As the number of readers purchasing and browsing for books online increases, the established publishing model of selling books to bricks and mortar stores has had to adapt to access a highly splintered new marketplace. Through their websites and social media accounts, publishers are engaging more with readers online.

Social media marketing is changing the relationship between publishers and readers. This connection need no longer be dominated by sales, but by mutually beneficial conversation and debate. It allows publishers the platform from which to

\footnotetext{
J. Criswell · N. Canty $(\bowtie)$

Centre for Publishing, University College London, Gower Street, London WC1E 6BT, UK

e-mail: n.canty@ucl.ac.uk
} 
build the trust of their readers directly, and tailor their output to specific readerships. This new situation also allows publishers to build their brands, because through social media readers use the publishers' pages to access information on titles and authors.

A contributing factor is the rise of smartphones and tablet computers, with 30.9 million such devices in use in the UK [1]. The UK has the second highest number of social media users in the EU with $70 \%$ of all UK residents currently use some sort of Social Media [2], spending an average of $17 \mathrm{~min}$ a day on their smartphones.

The underlying theme of social media marketing is to tap into or begin conversations on the medium, and use them for commercial benefit. Ideally this generates hype and word of mouth around the titles being promoted, and encourages people to purchase the book. There has been extensive analysis on what it is that influences consumers to spread the word on these sites, and what initiates 'viral' campaigns [3] or epidemics which can be more persuasive and targeted than traditional advertising as it is directed towards an interested audience. This idea of social epidemics was articulated by Malcolm Gladwell when analysing the exact moments when products go 'viral'. He identified three rules that cause them: the law of the few, the stickiness factor and the power of context [4]. The point here is that in order to achieve social popularity that spreads, a product must be used by socially adept individuals, be memorable, and be released into the right environment.

These arguments are applicable to social media marketing in the publishing industry [5]. Given the relationship social media enables between publishing companies and their readers there is the opportunity to spread word of mouth (WOM) and identify key individuals who might help promote a title online. By letting interested readers feel engaged and involved with the publishing process of a title, they are more likely to spread their excitement to other users.

Despite the advantageous effects of marketing via social media, some caution is needed. Social media cannot be treated as a conventional medium and arguably does not have scale built into it despite the assumption that the media side of social media will work to spread this engagement across the target audience. Companies should not assume results are guaranteed from using social media and an obsession with generating likes and followers is a misguided attempt to measure the success of campaigns. Social media strategies have to be targeted to be successful, and this success cannot be gauged by the number of likes and tweets alone. However, for the publishing industry, generating social media activity on a book is undoubtedly useful in spreading the word of a new title (Table 1).

\section{The Books}

Both books in this study are adult trade fiction titles in the 'fantasy' genre. Both titles were published within 8 months of each other, and thus the same websites and social media opportunities were available to marketers for both titles.

The Song of Achilles by Madeleine Miller, a debut author with no existing fan base, is a fictional story set in ancient Greece at the time of the Trojan War. The story follows Patroclus in a first-person narrative and details his loving, physical relationship with Achilles until his death at Troy. This original approach gives new 
Table 1 Key figures for the titles (Note-all figures up to 10 August 2013)

\begin{tabular}{lll}
\hline & The Song of Achilles & $\begin{array}{l}\text { The Wind Through the } \\
\text { Keyhole }\end{array}$ \\
\hline Publisher & Bloomsbury Publishing & Hodder \& Stoughton \\
Overall sales & 98,569 & 55,183 \\
Overall value of sales & $£ 618,796.94$ & $£ 477,630.35$ \\
Hardback sales & 4,499 & 34,236 \\
Paperback sales & 94,070 & 20,947 \\
Number of tweets about the book & 4,373 & 6,040 \\
Number of comments created & 42 & 19 \\
$\quad$ by Facebook pages & & 3,476 \\
Number of Facebook 'likes' received & 970 & 1,073 \\
Number of re-comments & 145 & \\
received & & \\
\hline
\end{tabular}

Fig. 1 The Song of Achilles

Hardback, £18.99. 5th

September 2011 (Bloomsbury)

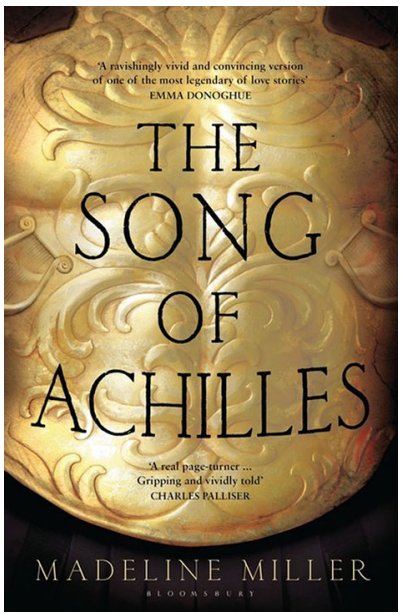

meaning to the great warrior's life, and appeals to the many fans of the Trojan War myth. The book was critically well received and it won the Orange Prize for Women's Fiction 2012 [6]. The Song of Achilles highlights the effects of social media marketing on debut titles, and the impact of literary awards on social media activity and sales (Figs. 1, 2).

The Wind Through The Keyhole by Stephen King is part of his Dark Tower series, which consists of eight books following the character Roland Deschain and his 'Ka-tet'. The books are set in the fictional region of 'Mid-world', in which Roland is on a quest to discover the dark tower. This novel came out after an eightyear delay, and fits chronologically in between books four and five of the series. The 
Fig. 2 The Song of Achilles Paperback, £7.99. 12th April 2012 (Bloomsbury)

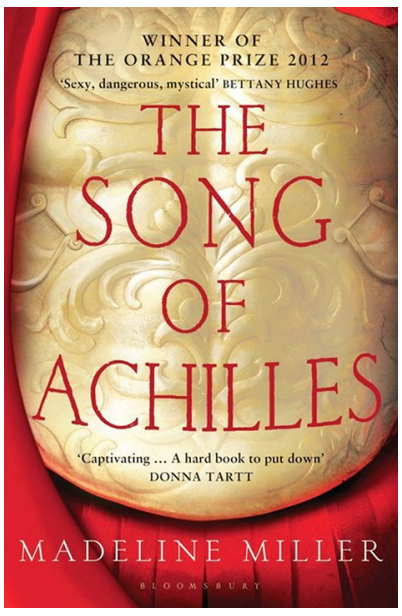

Dark Tower series mixes the western genre with fantasy sagas, and thus appeals to a wide range of readers who enjoy these genres.

Stephen King's fans are renowned for their intensity, with even King himself referring to them as his 'constant reader'. With such an iconic author and with such an enthusiastic fan base, there was a reliable, passionate community around the upcoming title.

Critically the book was well received, and seen as a 'gem' inserted into the 'enchanted series' [7]. The Wind Through the Keyhole showed the potential of a creative social media marketing campaign, and the impact of an established audience (Figs. 3, 4).

\section{The Research}

Over 10,000 posts were harvested from Facebook and Twitter and interviews were conducted with the marketing teams of each book to give context to the data. Sales data from Nielsen Bookscan was used to show whether social media activity impacted sales. Although Bookscan's timeline was monthly rather than daily it still allows an interesting progression of data to compare against the social media activity.

\section{Social Media Data}

Every tweet and Facebook comment made about the books since the date of their publication, through to the 10th August 2013 was tracked and catalogued. This required going back to the very first mentions of the titles on both Facebook and Twitter, and recording every piece of activity relating to them.

During the research several problems influenced the method. When documenting the tweets on both titles, some users' tweets were hard to categorize. To be 
Fig. 3 The Wind Through The

Keyhole Hardback, £19.99. 24th

April 2012 (Hodder \&

Stoughton)

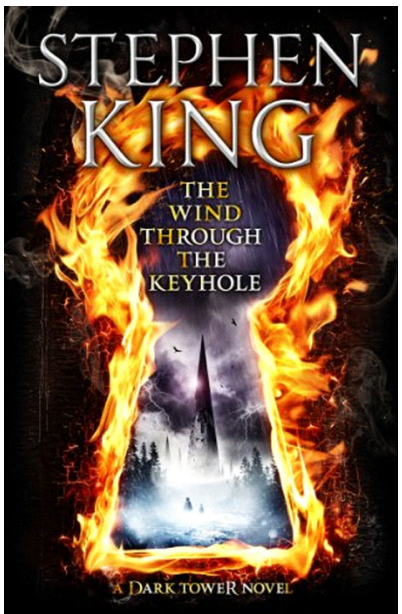

Fig. 4 The Wind Through The Keyhole Paperback, £7.99. 28th February 2013 (Hodder \& Stoughton)

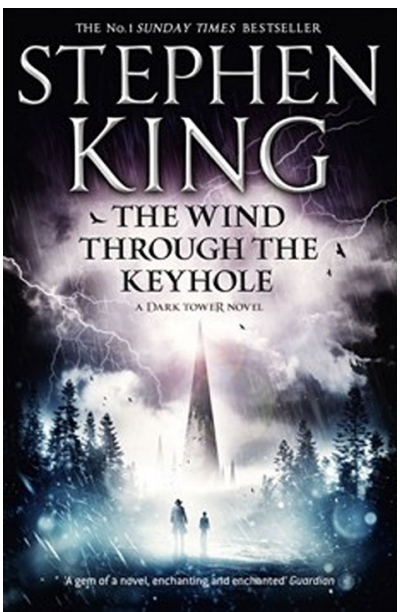

consistent, all their tweets were documented under the same heading. It was also often very difficult to tell the difference between bloggers and reviewers, so they were linked together under the same heading. It was also occasionally difficult to tell apart an enthusiastic reader from a blogger. This issue was solved on a case-bycase basis, examining the homepage of the user, and identifying whether or not they had an established blog page.

Another issue concerned tweets from readers' Goodreads pages. Given the site's popularity there were many Goodreads reviews of the chosen titles on Twitter. These reviews were documented under 'reader', rather than under 'blogger \& reviewer', because Goodreads is a platform built for readers to express their thoughts, not blog posts. 


\section{Twitter}

Twitter generates a higher number of individual interactions than Facebook, and there were many thousand tweets about each title. The history of tweets on a subject can be accessed by searching for it under the 'all' search option. Rather than limit the search to the titles' or publishers' specific Twitter pages, tweets were instead gathered from the entire stream of conversation around the titles of these books back to their very first mention. This method delivered a timeline of Twitter activity throughout the books' lifespans, including information on different users. To differentiate between users who were tweeting about the titles the tweets were classified into groups (Table 2).

It was necessary to differentiate between 'all publishers' and 'individual publishers' because there were often tweets made by the American or Australian sister publishing companies.

Whilst gathering information from Twitter for both titles no 'conversations' were expanded. This would have been misleading, because, as with face--to--face conversations, very few maintained the subject of the titles all the way through. The number of retweets each comment received was also not recorded as it would have been impractical to enter each tweet individually to find this information. Instead, the research details the number of original tweets, and compares it to the number of sales for each title.

\section{Facebook}

Extracting useful information from Facebook required a different approach. Facebook is set out in such a way that the activity on the site is far more contained and there is nothing like Twitter's stream of conversation about a subject, and searches direct the user to specific pages. Facebook is defined by these pages which users can choose to 'like' and interact with.

This presented a problem, because there was an immense range of Facebook pages on The Song of Achilles and The Wind Through the Keyhole, from the publishers' own pages to fan--sites dedicated to the books. In order to make the research as accurate as possible, data was gathered only from the Facebook pages which were officially run by publishers Hodder \& Stoughton and Bloomsbury. This included the site dedicated to the book by its publisher, and the publisher's own site although the majority of social media activity was on the titles' dedicated pages. For The Wind Through the Keyhole data was gathered from the Hodder \& Stoughton Facebook homepage, and also the publisher's page titled 'Stephen King Books', as there was no single page dedicated to the title run by Hodder \& Stoughton. For The Song of Achilles, the data was sourced from the Bloomsbury Facebook homepage

Table 2 Categories to define user groups on Twitter

\begin{tabular}{llll}
\hline $\begin{array}{l}\text { All publishers } \\
\text { Reviewers }\end{array}$ & Individual publisher & Readers & Bloggers \\
& Booksellers & Author & Libraries \\
\hline
\end{tabular}


Table 3 Categories to define Facebook users and content types

\begin{tabular}{llll}
\hline Page & Readers & Booksellers & Publisher \\
Text & Image & Video & Library \\
\hline
\end{tabular}

and the publisher's page dedicated to The Song of Achilles. For each comment the number of likes, re-comments and shares the title had accumulated was recorded.

To distinguish the different users who interacted with the Facebook page their comments were separated by page, readers, booksellers, publisher and libraries. Furthermore it was recorded whether each comment was text, an image or video (Table 3).

On Facebook, the context of comments under each post was not analyzed. This was unnecessary, as the comments were often similar, and investigating each one did not reveal anything new.

\section{Limitations of the Research}

The research did not include comments from any fan--made or authors' pages. Including these pages would have resulted in incomparable data for the titles; Stephen King has a large number of Facebook pages dedicated to him and his books while Madeline Miller does not. Also, Madeline Miller has an active presence on her Facebook page, whereas Stephen King's social media presence is recent, with his Twitter account @StephenKing opening after this research was conducted.

Nielsen Bookscan does not record ebook sales and has been criticized for giving an incomplete view of the market although it claims to cover $90 \%$ of the consumer market [8]. Nielsen Bookscan was the most reliable source of sales data that was available and its information on the physical sales of books gave an understanding of the fluctuations in sales.

\section{Results}

The Song of Achilles

\section{Overview of Social Media Marketing Activity}

The social media marketing campaign for The Song of Achilles was reactive, rather than proactive and it was only after the Orange Prize Longlist announcement Bloomsbury became more active on Facebook and Twitter. Press reviews, images and highlighted author events were added to maintain the hype caused by the Orange Prize announcement. Bloomsbury also used Madeline Miller in several author videos which they posted on Facebook and tweeted about. By establishing sites for Madeline Miller's first book, they hoped to provide a decent platform from which to launch a campaign should she write a second (Table 4). 
Table 4 The Song of Achilles Key dates

\begin{tabular}{ll}
\hline Date & Key event \\
\hline 21st April 2011 & First Facebook comment \\
22nd April 2011 & First Tweet \\
5th September 2011 & Hardback published \\
7th March 2012 & Orange Prize longlist announced \\
12th April 2012 & Paperback published \\
17th April 2012 & Orange Prize shortlist announced \\
30th May 2012 & Orange Prize victory \\
5th April 2013 & Independent Bookseller Award shortlist announced \\
30th May 2013 & Amazon Kindle deal of the day \\
7th August 2013 & Guardian's August book reading group \\
\hline
\end{tabular}

Twitter

Table 5 is a summary table of the accumulated Twitter research for The Song of Achilles, and tracks all Twitter activity on the title from its first tweet on the 22nd April 2011, to the 10th August 2013. In the course of the research on this title, 4,373 tweets were recorded.

The two groups who dominated the activity on Twitter were readers, with 2,513 tweets, $57.5 \%$ of total, and the bloggers and reviewers with 1,347 tweets, $30.8 \%$ of total. The remaining groups contributed 513 tweets, making up $13.0 \%$ of the total number, including Bloomsbury's contribution of 52 tweets. This was $1.2 \%$ of the total, but shows a lot of activity given the campaign started as reactive. Madeline Miller's 33 tweets show a very active contribution which was immensely valuable for Bloomsbury. A surprising statistic, given the critical success of the title, is that only $4.2 \%$ of the Twitter activity was by booksellers, suggesting they are less likely to gamble and engage with new titles (Fig. 5).

Figure 6 shows there was very little activity on publication date of either Hardback or Paperback editions, with only 3 and 4 tweets respectively. There is a spike of activity on the 30th and 31st of May 2012 which was due to the Orange Prize victory on the 30th May, which resulted in 392 tweets on the 30th May, and 300 on the 31st May. There are other, smaller peaks in the timeline. The first peak consisted of 47 tweets on the 6th March and 20 tweets on the 7th of March 2012, caused by the announcement of the Orange Prize Longlist. The second peak shows 57 tweets made on the 30th May 2013, when Amazon made The Song of Achilles its Kindle deal of the day. The average number of tweets a day over the entire timeframe was 6.6.

Figure 7 shows the Orange Prize win is the pinnacle for all user groups. In the early months the 'bloggers \& reviewers' were the main contributors to the feed. Reader activity picked up around February 2012, heightened around the Orange Prize, and then continued to be strong up until the 10th August 2013 where tweets were almost exclusively by readers. This is down to the fact that 'bloggers \& 
Table 5 Summary table of Twitter activity for 'The Song of Achilles'

\begin{tabular}{llllllll}
\hline $\begin{array}{l}\text { The total } \\
\text { number of } \\
\text { tweets }\end{array}$ & $\begin{array}{l}\text { Tweets by } \\
\text { publishers } \\
\text { (incl. } \\
\text { Bloomsbury) }\end{array}$ & $\begin{array}{l}\text { Tweets by } \\
\text { Bloomsbury }\end{array}$ & $\begin{array}{l}\text { Tweets } \\
\text { by } \\
\text { readers }\end{array}$ & $\begin{array}{l}\text { Tweets by } \\
\text { bloggers \& } \\
\text { reviewers }\end{array}$ & $\begin{array}{l}\text { Tweets by } \\
\text { booksellers }\end{array}$ & $\begin{array}{l}\text { Tweets } \\
\text { by } \\
\text { author }\end{array}$ & $\begin{array}{l}\text { Tweets } \\
\text { by } \\
\text { libraries }\end{array}$ \\
\hline 4373 & 185 & 52 & 2513 & 1,347 & 184 & 33 & 113 \\
$100 \%$ & $4.2 \%$ & $1.2 \%$ & $57.5 \%$ & $30.8 \%$ & $4.2 \%$ & $0.8 \%$ & $2.6 \%$ \\
\hline
\end{tabular}

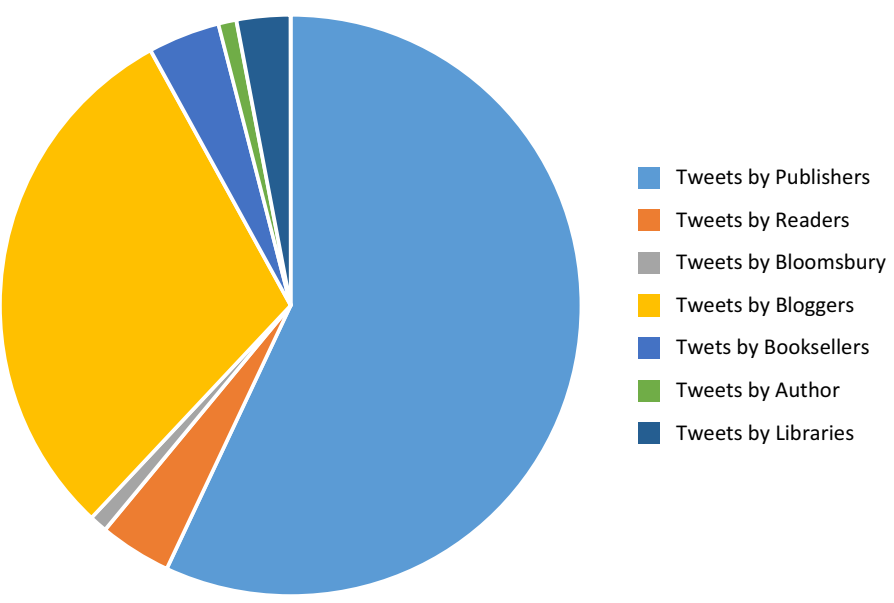

Fig. 5 The distribution of tweets by user group for The Song of Achilles

Timeline of Daily activity for 'The Song of Achilles'

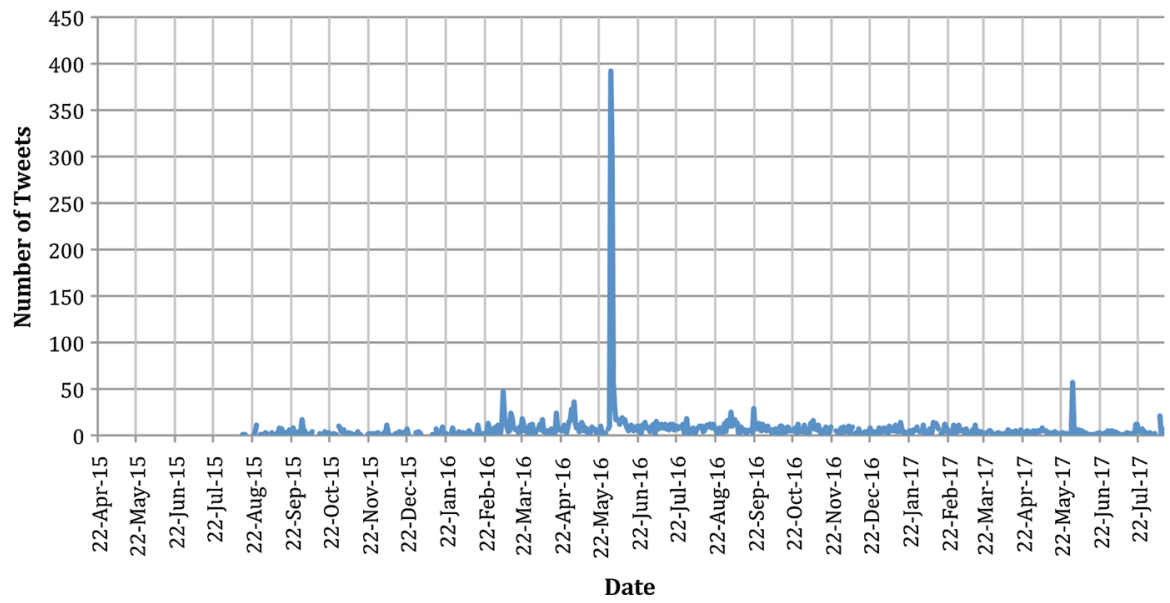

Fig. 6 Timeline of daily Twitter activity for The Song of Achilles 


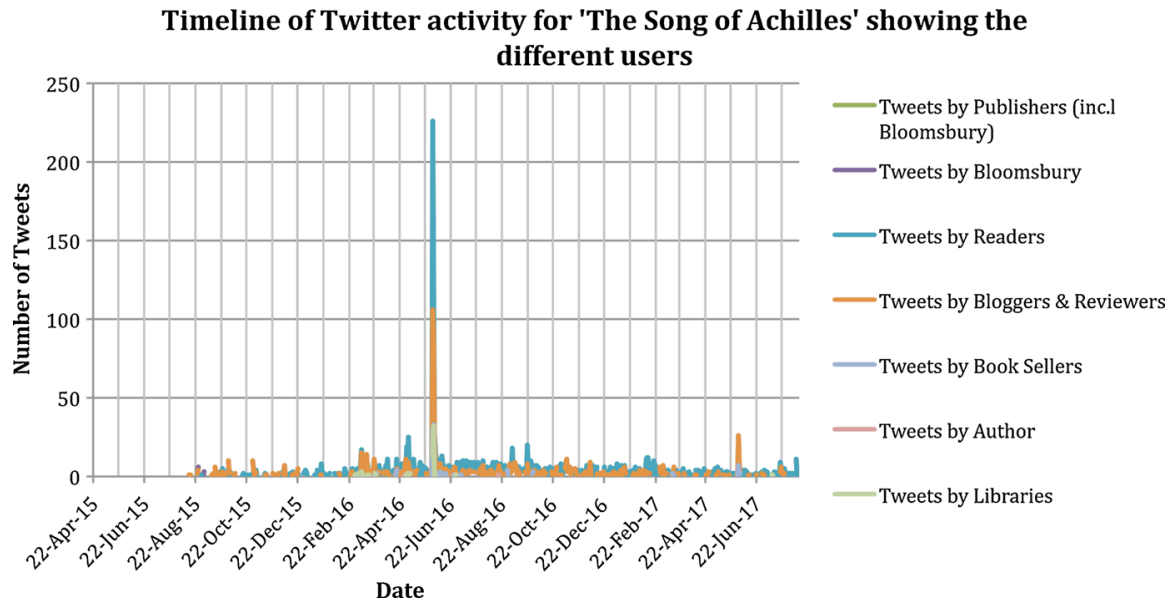

Fig. 7 Timeline of Twitter activity for The Song of Achilles by different user group

Graph showing the accumulated number of tweets over 'The Song of Achilles' lifespan

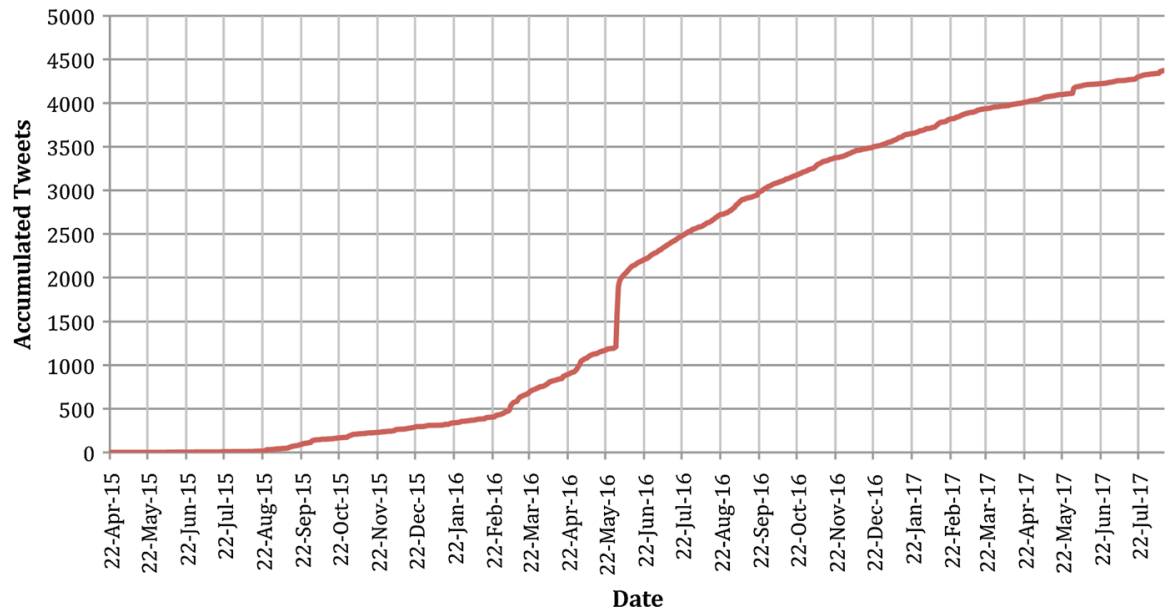

Fig. 8 Accumulated number of Tweets over the lifetime of The Song of Achilles

reviewers' are often given advanced information and copies of upcoming titles (Figs. 8, 9).

\section{Facebook}

The Bloomsbury Facebook page (Facebook.com/BloomsburyPublishing) featured only two comments on The Song of Achilles and Bloomsbury concentrated their activity for the page devoted The Song of Achilles (Facebook.com/SongofAchilles). On the 10th August, this page had 1,674 likes, and 151 comments. According to 


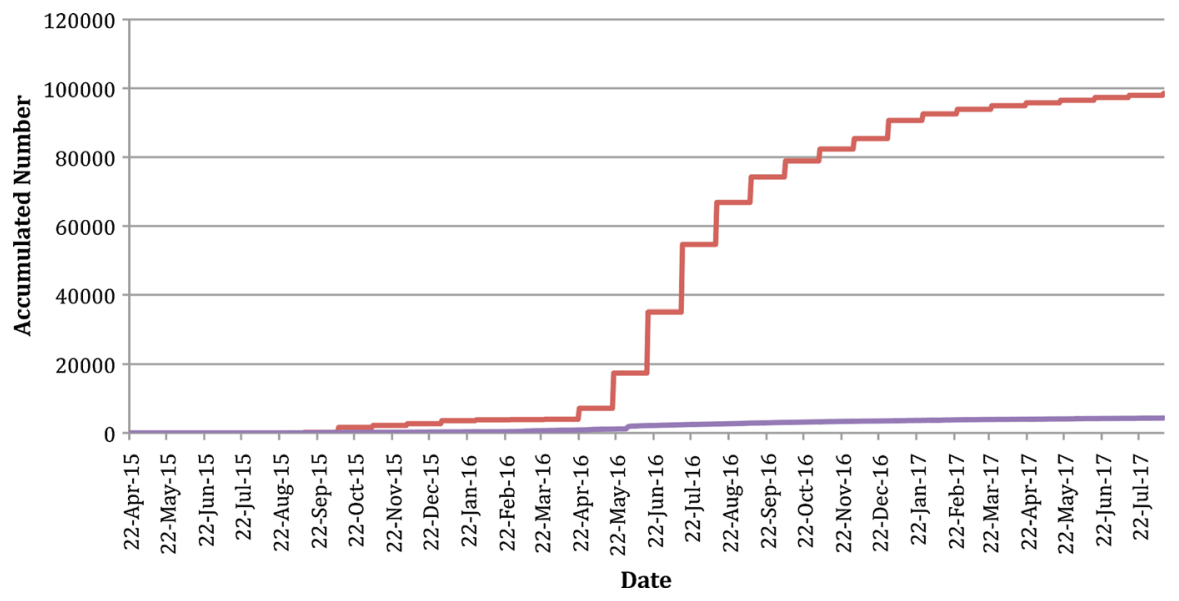

Fig. 9 Timeline of Twitter and sales activity

Table 6 Breakdown of Facebook comments made on 'The Song of Achilles' page

\begin{tabular}{llllll}
\hline $\begin{array}{l}\text { Total } \\
\text { comments }\end{array}$ & $\begin{array}{l}\text { Comments } \\
\text { by page }\end{array}$ & $\begin{array}{l}\text { Comments } \\
\text { by readers }\end{array}$ & $\begin{array}{l}\text { Comments by } \\
\text { booksellers }\end{array}$ & $\begin{array}{l}\text { Comments by } \\
\text { Bloomsbury } \\
\text { departments }\end{array}$ & $\begin{array}{l}\text { Comments by } \\
\text { libraries and } \\
\text { institutes }\end{array}$ \\
\hline 151 & 42 & 100 & 6 & 2 & 1 \\
$100 \%$ & $27.8 \%$ & $66.2 \%$ & $4.0 \%$ & $1.3 \%$ & $0.7 \%$ \\
\hline
\end{tabular}

Facebook, the 23rd September 2012 was the title's most popular week, with 18-24 year olds as the most popular age group. The 151 comments were documented according to which user group had created them. Table 6 shows the breakdown of the number of comments made by the various users.

The dominant user group on Facebook were readers, who created $100(66 \%)$ of the comments suggesting a high level of engagement. The 42 comments by the page, making up $28 \%$ of the total number, shows that Bloomsbury commented regularly in order to keep reader activity high. The other figures concerning the booksellers, libraries and Bloomsbury departments are expectedly a small percentage of the total, making up only $6 \%$ of comments combined. Clearly these user groups are less likely to engage with new titles on Facebook (Table 6).

Textual comments $(82 \%)$ were the most popular (Table 7). These comments, in all forms, gathered 1,011 likes, 157 re-comments, and 69 shares (Figs. 10, 11).

There are four major peaks here, the largest of which is on the 30th May, due to the Orange Prize victory (Fig. 12). The others were down to the release of a video trailer (9/09/11), the announcement that Madeleine Miller was coming to the UK (28/08/12) and several comments by readers (13/11/12). 
Table 7 The formats of the comments made on Facebook

\begin{tabular}{lllll}
\hline Format & Text & Photo & Video & Event announced \\
\hline Number of comments & $124(82 \%)$ & $11(7 \%)$ & $5(3 \%)$ & $12(8 \%)$ \\
\hline
\end{tabular}

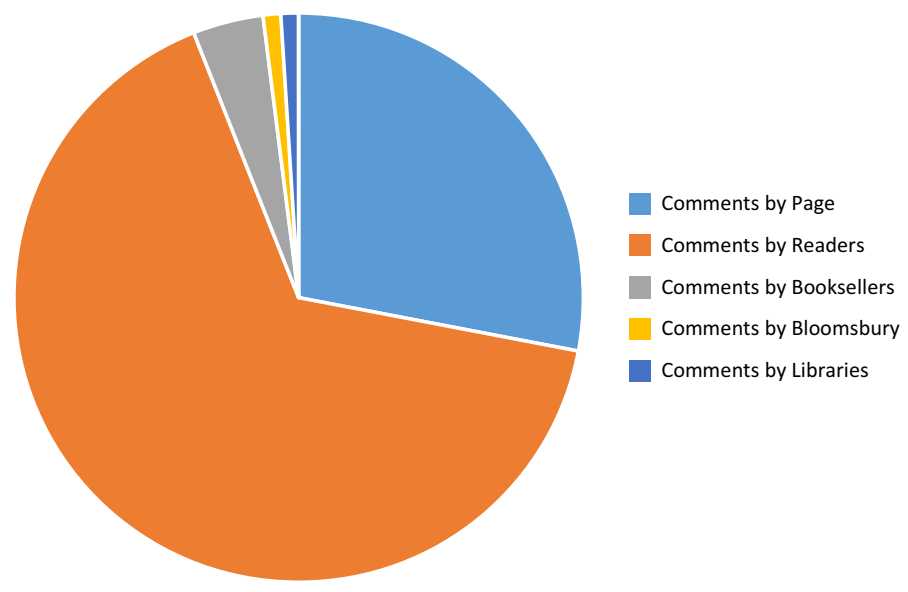

Fig. 10 Breakdown of Facebook comments made on 'The Song of Achilles'

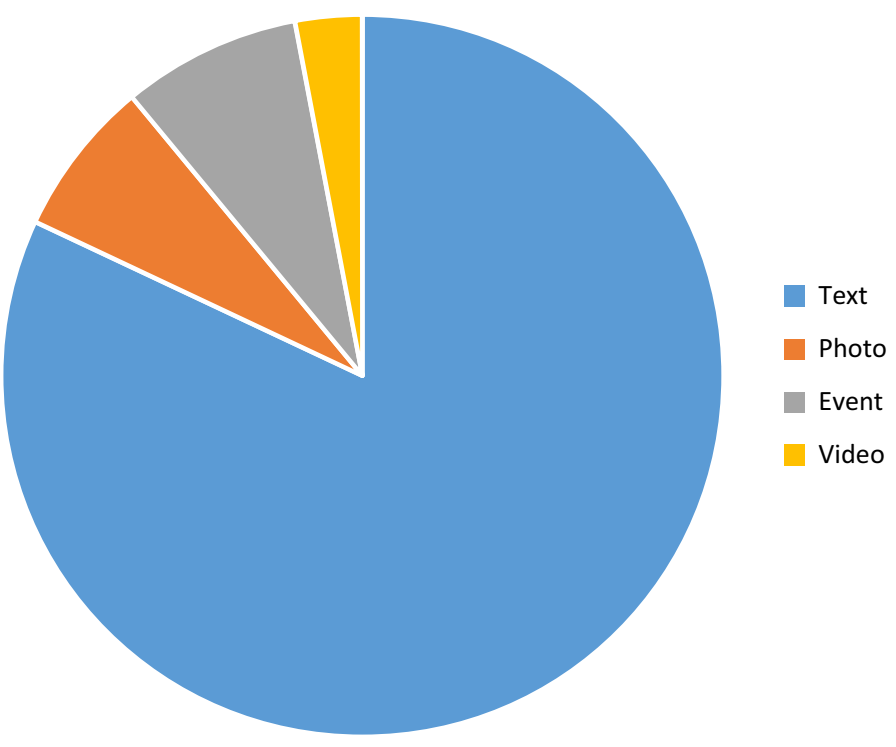

Fig. 11 Breakdown of the formats used by the groups to comment 


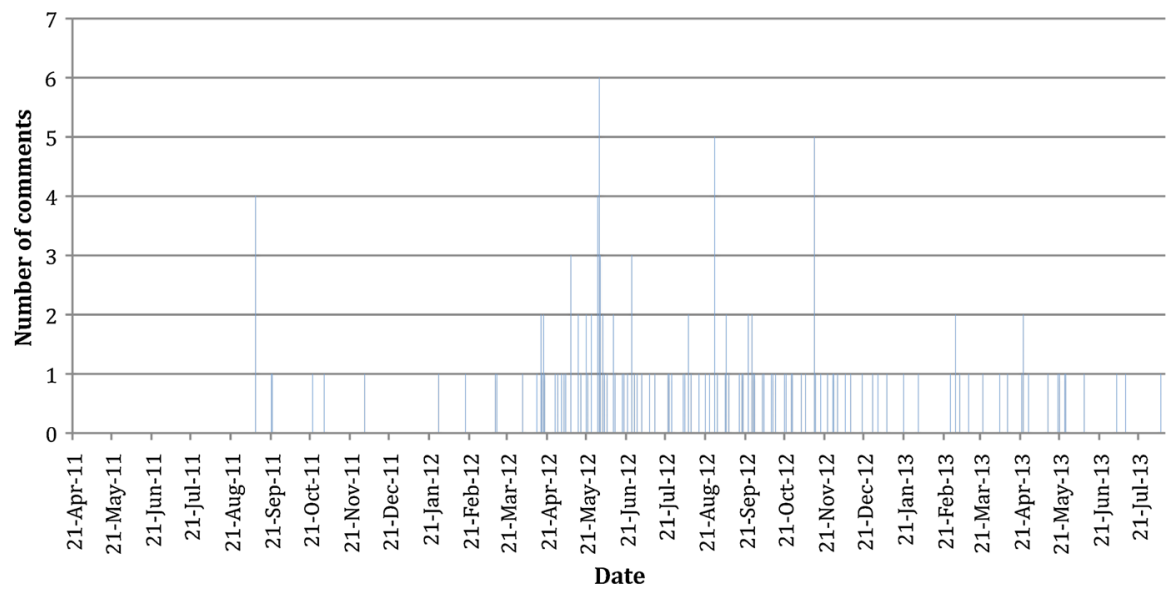

Fig. 12 Timeline of Facebook comments made on 'The Song of Achilles'

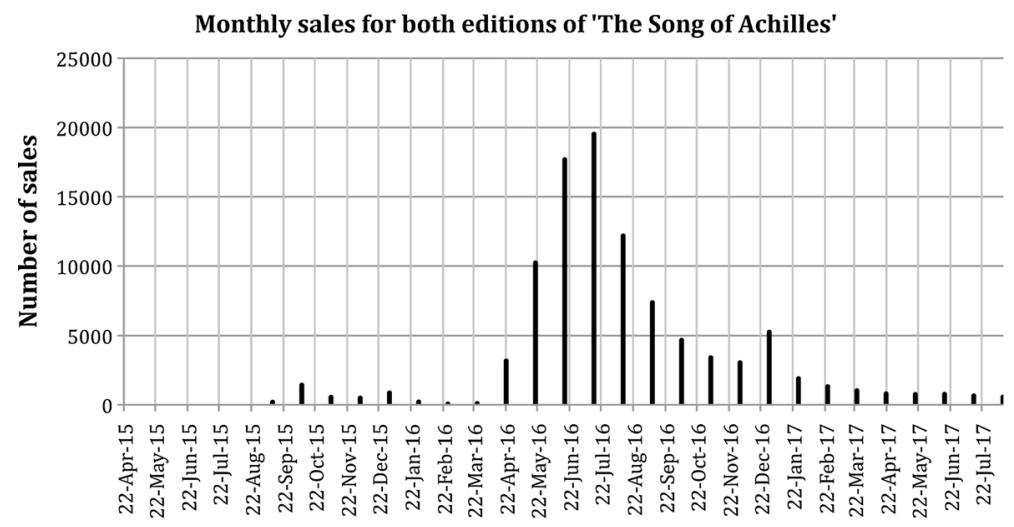

Date

Fig. 13 Monthly sales of both editions of 'The Song of Achilles'

\section{Nielsen Bookscan Data}

The editions of The Song of Achilles sold 98,569 units by the 10th August 2013, with a total value of $£ 618,796.94$. Figure 13 below shows the number of sales each month for both the paperback and hardback editions.

Figure 14 shows the sales figures of The Song of Achilles Hardback edition. This edition sold 4,499 copies, accumulating a value of $£ 62,255.29$. This began well, with 1,444 sold in the period ending the 8th October 2011, followed by 3 months of continued good sales of 562, 503 and 877 units respectively. However, after the period ending the 31st December 2011 the sales decreased. There is one more flourish of 176 sales in the period ending the 16th June 2012, due to the Orange Prize victory on the 30th May 2012. The best period of sales, 
ending on the 8th October 2011, made up $32.1 \%$ of all sales of this edition (Fig. 14).

Figure 15 shows the sales figures of The Song of Achilles Paperback edition. This edition sold 94,070 copies in total, accumulating a value of $£ 556,541.65$.

The edition's sales started off incredibly well, with 50,298 units sold in only five months. The particularly impressive periods ending 16th June 2012 and 14th July 2012 recorded 17,519 and 19,503 sales respectively. Clearly the Orange Prize award, on the 30th May 2012, influenced enormous sales in these periods. The slow decline of sales over the last 6 months, from the period ending the 23rd March 2013 to that ending 10th August 2013, highlights how readers are still drawn to this title.

\section{Stephen King}

\section{Overview of the Social Media Strategy}

Hodder \& Stoughton's strategy for this book was to conduct a creative social media marketing campaign that would both appeal to the loyal fans and generate excitement. They decided on the 'StephenKingFaces' competition, which offered fans the chance to be on the cover of The Wind Through the Keyhole. Fans had to email in headshot images of themselves, and Hodder then selected ' 8,000 faces' to be included in the back cover of the Hardback version. For the Paperback Hodder \& Stoughton decided to use a similar tactic, and asked fans to send in their reviews to be included in the edition (Table 8).

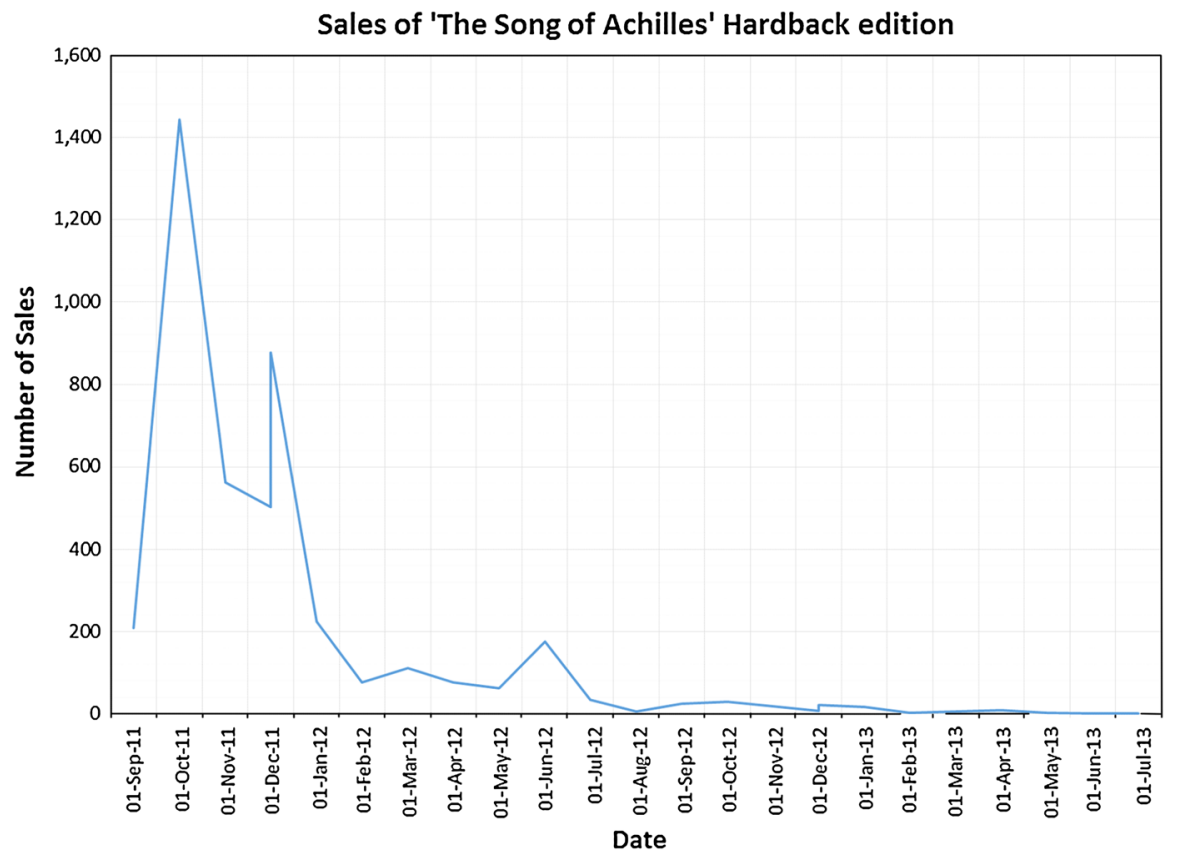

Fig. 14 Sales of 'The Song of Achilles' Hardback edition 


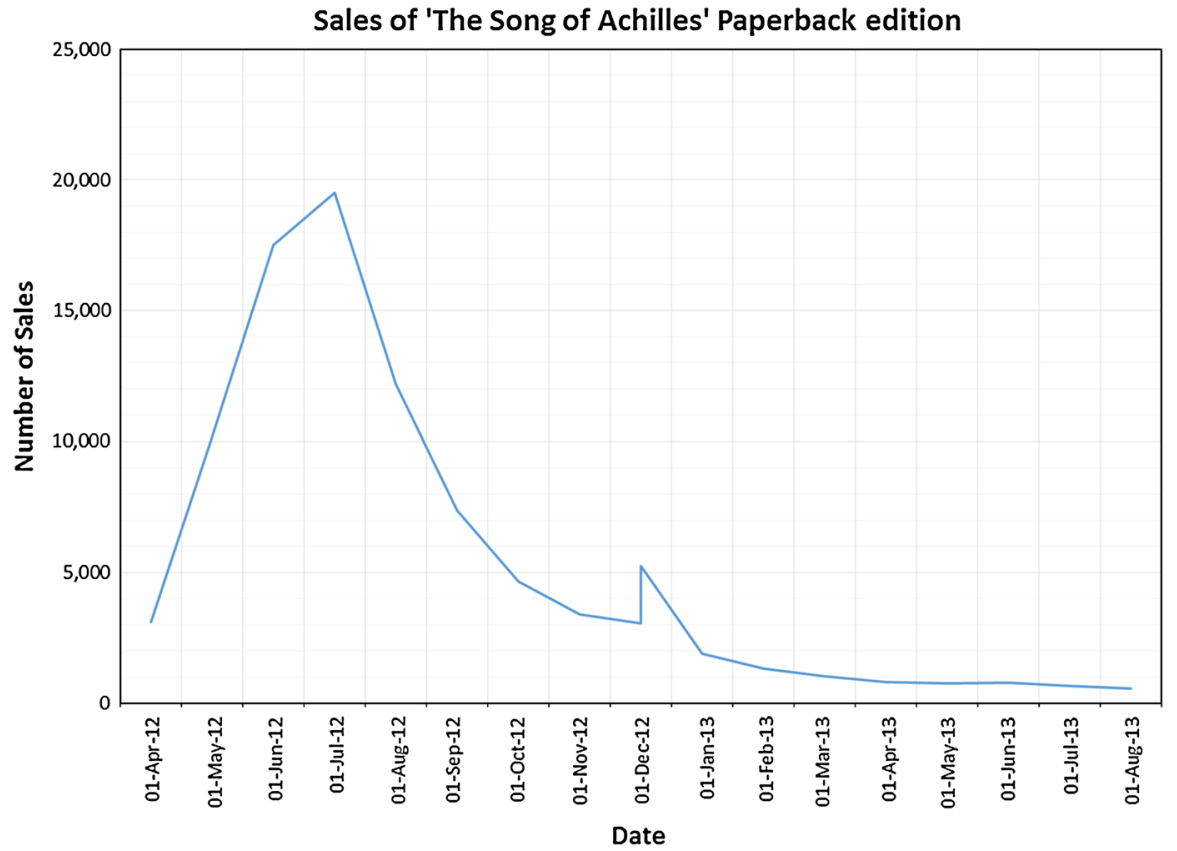

Fig. 15 Sales of 'The Song of Achilles' Paperback

Table 8 Key dates for Wind through the keyhole

\begin{tabular}{ll}
\hline Date & Key event \\
\hline 9th November 2009 & First Tweet \\
10th March 2011 & Book's 2012 release announced \\
14th June 2011 & Hodder announce publication in 2012 \\
24th August 2011 & Synopsis announced \\
19th December 2011 & Excerpt of text released \\
16th January 2012 & Announced the 'Faces' competition \\
23rd January 2012 & Deadline for 'Faces' submission \\
8th March 2012 & Announce that Stephen King will read his own audiobook \\
17th April 2012 & Faces of those on the cover released. \\
24th April 2012 & Release of Hardback \\
2nd May 2012 & No. 1 on the New York Times Hardcover fiction list \\
18th May 2012 & Video interview with Stephen King \\
22nd July 2012 & Ask fans to post their own reviews \\
1st November 2012 & Offer fans the chance to get their reviews in the Paperback \\
19th February 2013 & Release of book trailer \\
28th February 2013 & Paperback released \\
\hline
\end{tabular}


In tandem with these creative methods, Hodder \& Stoughton released regular information about the book many months before its publication. By commenting on the book so early, Hodder \& Stoughton instigated renewed discussion about the 'Dark Tower' series to generate interest and influence more sales.

\section{Twitter}

The number of tweets for this title surpasses that of The Song of Achilles by 1,667, showing more engagement from users. The readers were the most active users, creating 3,166 tweets, $52 \%$ of the total number. This figure was followed by bloggers \& reviewers, who created 2,297 tweets, $38 \%$ of the total number on the title. The remaining categories are surprising, in that there is a large number of tweets, 466, by booksellers, and almost none, 40, by libraries. Booksellers evidently wanted to exploit the sales potential of a new Stephen King book. Another fascinating statistic is that there are only 13 tweets by Hodder (Fig. 16; Table 9).

Given the early announcement of the publication of this book in November 2009, there is a long period of Twitter silence at the beginning of the Timeline. There is then a spike of activity caused by the publication of the Hardback, which reached 330 tweets on the day of release. This spike is protracted, because the frenzied Twitter activity lasted for many days, from approximately the 10th April 2012 to the 28th of May 2012, thanks to the gradual release of content by Hodder and the fans' anticipation for the book's release.

Figure 17 also shows two other significant peaks of activity over 50 tweets. The first peak of 81 tweets, on the 10th March 2012, was caused by the information that The Wind Through the Keyhole would be published in 2012. The second peak of 59 tweets, on the 4th of March 2013, was caused both by the publication of the Paperback on the 28th February 2013, and by Hodder announcing they were giving away the 'Dark Tower' novels in a competition (Fig. 18).

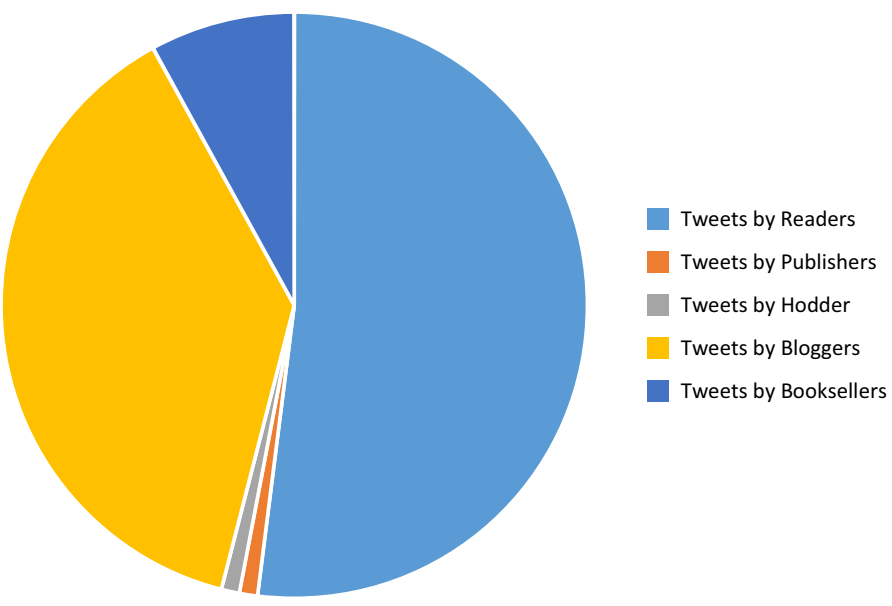

Fig. 16 Distribution of tweets by user group for The Wind Through the Keyhole 
Table 9 Summary of Twitter research for 'The Wind Through the Keyhole'

\begin{tabular}{lllllll}
\hline $\begin{array}{l}\text { Total number } \\
\text { of tweets }\end{array}$ & $\begin{array}{l}\text { Tweets by } \\
\text { publishers } \\
\text { (incl } \\
\text { Hodder) }\end{array}$ & $\begin{array}{l}\text { Tweets by } \\
\text { Hodder }\end{array}$ & $\begin{array}{l}\text { Tweets by } \\
\text { readers }\end{array}$ & $\begin{array}{l}\text { Tweets by } \\
\text { bloggers \& } \\
\text { reviewers }\end{array}$ & $\begin{array}{l}\text { Tweets by } \\
\text { booksellers }\end{array}$ & $\begin{array}{l}\text { Tweets by } \\
\text { libraries }\end{array}$ \\
\hline 6,040 & 70 & 13 & 3,166 & 2,297 & 466 & 40 \\
$100 \%$ & $1.2 \%$ & $0.2 \%$ & $52.4 \%$ & $38.0 \%$ & $7.7 \%$ & $0.7 \%$ \\
\hline
\end{tabular}

Timeline of daily Twitter activity for 'The Wind Through the Keyhole'

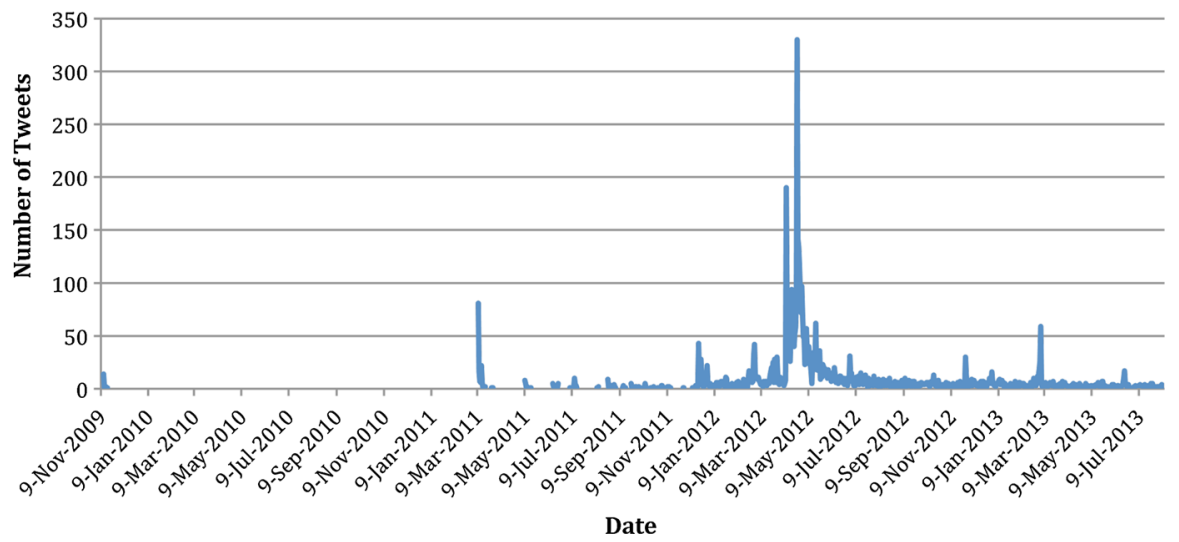

Fig. 17 Timeline of Twitter activity for The Wind Through the Keyhole

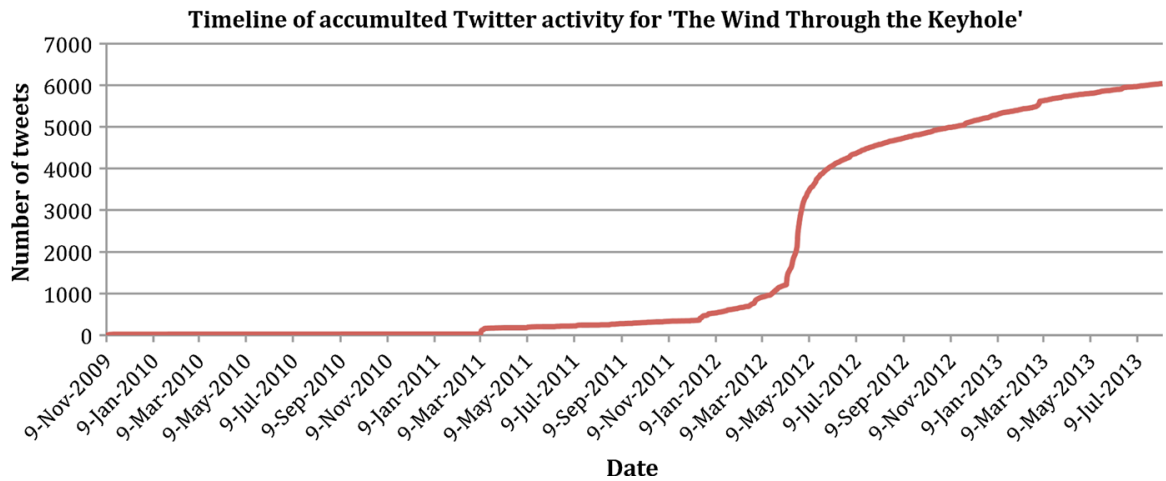

Fig. 18 Timeline of accumulated Twitter activity for The Wind Through the Keyhole

Figure 19 identifies which user groups were active along the timeline of the book. The activity by readers remained a constant presence throughout the book's life, and the peaks in March 2011 and March 2013 both mainly consisted of reader engagement. However, the bloggers and reviewers user group saw concentrated activity before and during the publication of the Hardback, but afterwards their 


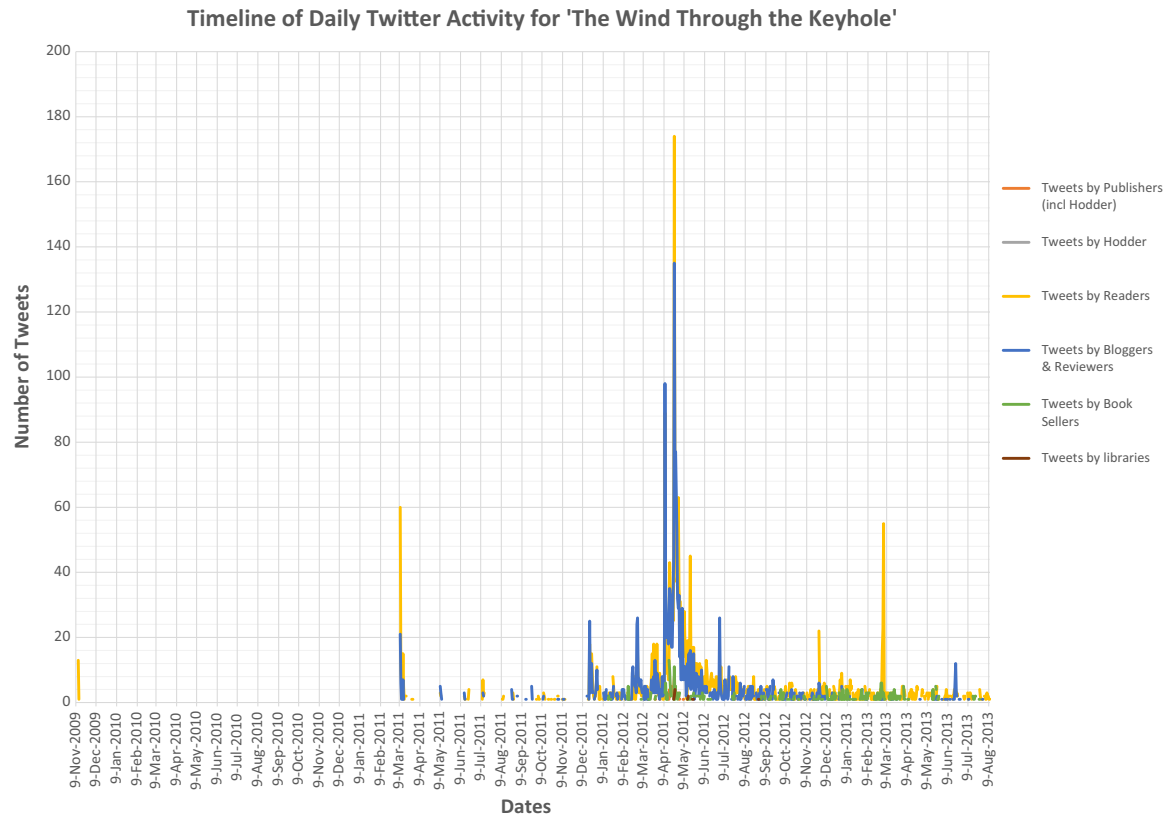

Fig. 19 Timeline for 'The Wind Through the Keyhole' by user group

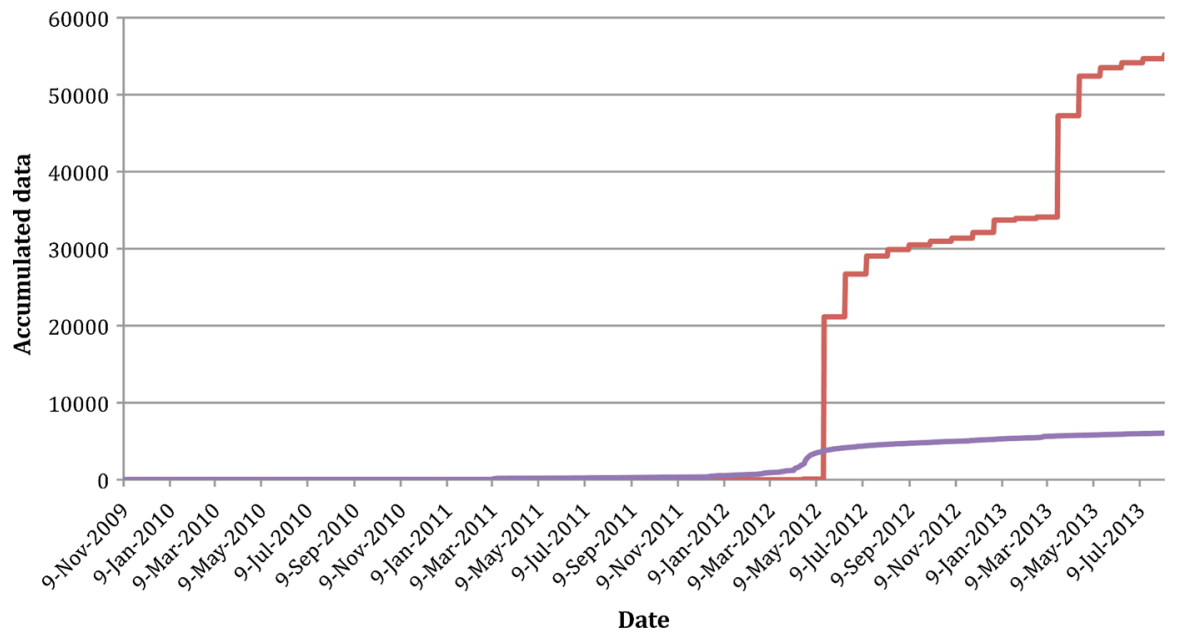

Fig. 20 Comparison of Twitter activity to sales figures for 'The Wind Through the Keyhole'

involvement lessened significantly. Booksellers rarely commented before the Hardback publication, but became much more active during the hype around it, and after the event. Clearly they were keen to take advantage of the guaranteed popularity of the new title (Fig. 20). 


\section{Stephen King Facebook}

There were no comments on the book on the Hodder \& Stoughton Facebook page (Facebook.com/Hodder-Stoughton) However, Hodder \& Stoughton set up a single Facebook page for all of Stephen King's books which had 182,546 likes on this page, though this cannot be seen as being solely because of The Wind Through the Keyhole. According to Facebook 25-34 years old is the most regular age group visiting the page, which is a reliable representation of Stephen King's readership (Table 10).

There is no range in users who comment on the book's page, only readers and the page itself. Booksellers and libraries clearly did not see this site as a means of gathering consumers. Interestingly, the 19 comments made by the page outnumber the 12 made by readers. One would have expected more reader--based original activity. The comments were all textual except an image of the audiobook cover. As Table 11 shows, readers engaged heavily with Hodder \& Stoughton's 19 comments.

This is huge engagement for only 31 comments made on the entire page. Figure 21 shows the timeline of likes, re-comments and shares for this book.

Table 10 Facebook comments made on 'The Wind Through the Keyhole'

\begin{tabular}{llllll}
\hline $\begin{array}{l}\text { Total } \\
\text { comments }\end{array}$ & $\begin{array}{l}\text { Comments } \\
\text { by page }\end{array}$ & $\begin{array}{l}\text { Comments } \\
\text { by readers }\end{array}$ & $\begin{array}{l}\text { Comments by } \\
\text { booksellers }\end{array}$ & $\begin{array}{l}\text { Comments } \\
\text { by Hodder } \\
\text { departments }\end{array}$ & $\begin{array}{l}\text { Comments by } \\
\text { libraries } \\
\text { and institutes }\end{array}$ \\
\hline 31 & 19 & 12 & 0 & 0 & 0 \\
$100 \%$ & $61 \%$ & $39 \%$ & $0 \%$ & $0 \%$ & $0 \%$ \\
\hline
\end{tabular}

Table 11 Interactions with the comments on the Facebook page of 'The Wind Through the Keyhole'

\begin{tabular}{lll}
\hline Likes & Re-comments & Shares \\
\hline 3,482 & 1,074 & 327 \\
\hline
\end{tabular}

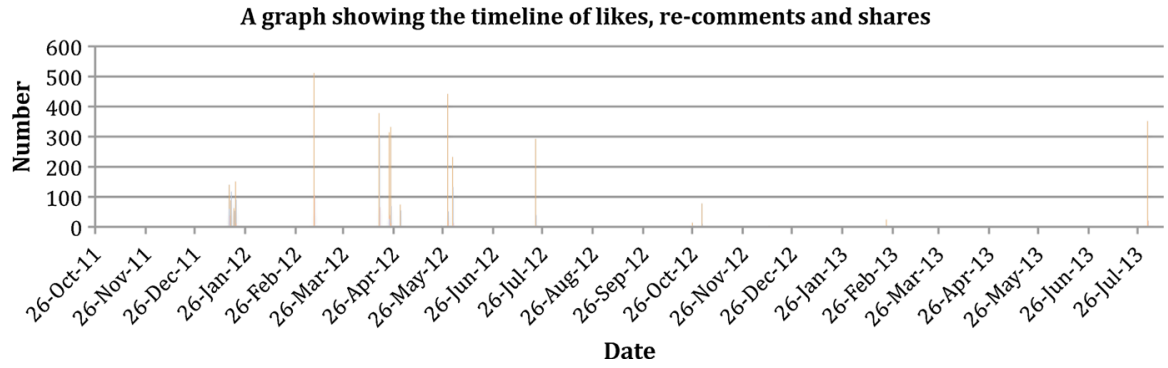

Fig. 21 Timeline of Facebook activity 


\section{Nielsen Data Research}

The Hardback sold 34,236 units, a huge figure for Hardback sales. There is a spike of immediate activity, selling at its peak 21,083 units in 1 month, in the period ending the 19th May 2012. This peak is followed by a swift decrease in sales,

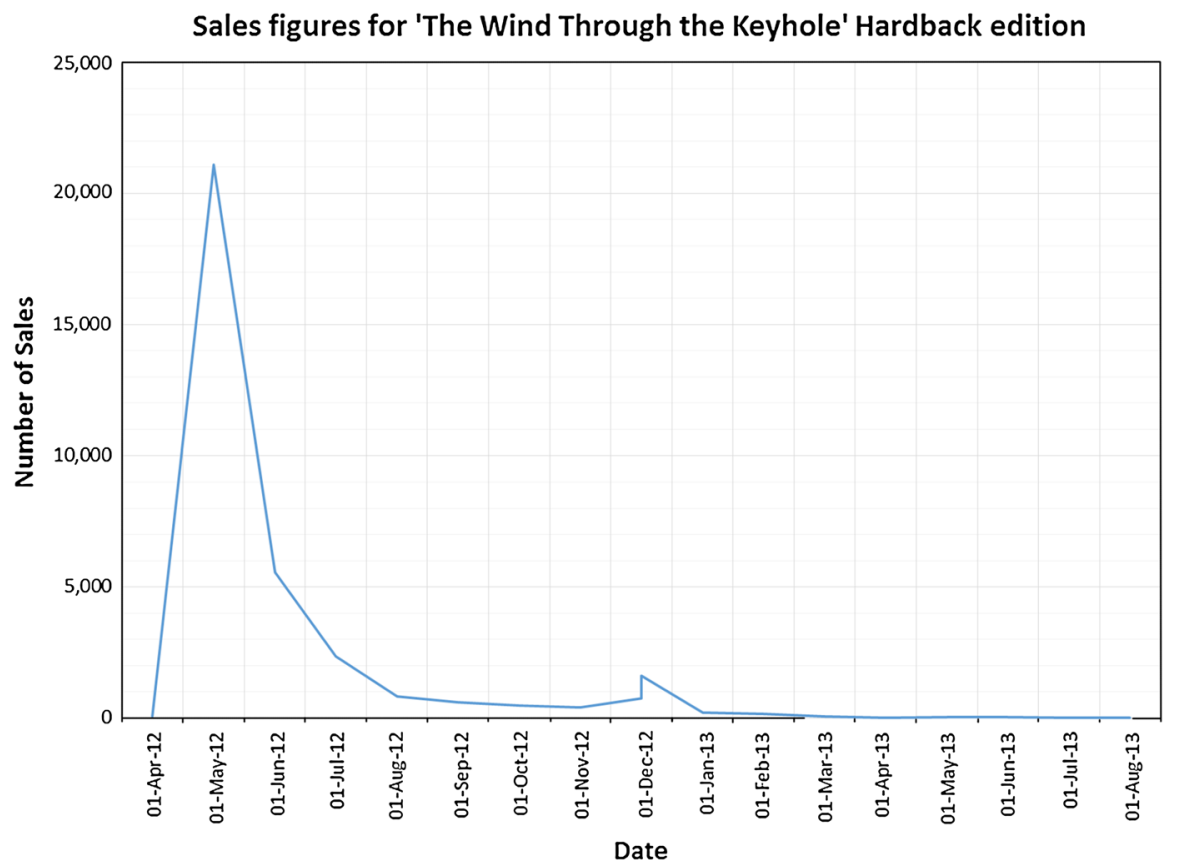

Fig. 22 Sales for 'The Wind Through the Keyhole' Hardback edition

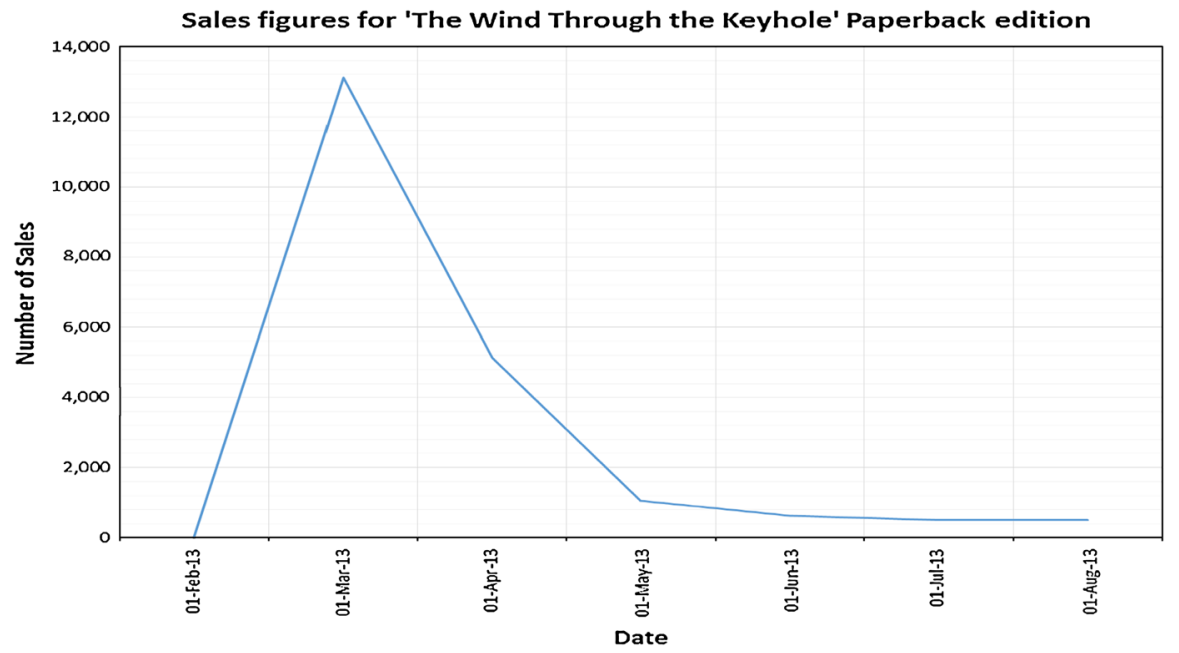

Fig. 23 Sales figures for 'The Wind Through the Keyhole' Paperback edition 
dropping to 5,549 the next month, and the number continues to trail off with only one more sales spike around Christmas (Figs. 22, 23).

For the Paperback, there is again one large peak of sales, which reaches a maximum of 13,112 sales in the period ending the 23rd March 2013. There is again a swift decline in sales, down to 5,124 and then 1,059 units in the next two months. Given the 34,236 sales of the Hardback edition, the 21,161 units sold in Paperback seems unsubstantial.

\section{Analysis}

The research provided an insight into the effect of social media activity surrounding the chosen titles, and also showed the impact of contributing factors such as existing readerships and literary prize nominations.

The Song of Achilles gained more sales in its lifespan than The Wind Through the Keyhole, selling 98,569 units $(£ 618,796.94)$ over 55,407 (£479,102.02). Even with the 7 month head-start, this is still a considerable difference. However, The Song of Achilles generated far less social media activity with its campaigns than The Wind Through the Keyhole. Bloomsbury amassed 4,737 tweets on Twitter, and 1,011 likes, 157 re-comments and 69 shares on Facebook. This is an impressive tally, but is insubstantial compared to the 6,040 tweets, 3,482 likes, 1074 re-comments and 327 shares gathered by Hodder \& Stoughton. Interestingly, the title that gathered the most social media interaction did not gain the most sales.

The dominant user group for both titles was readers. This user group created an average of $54.5 \%$ of all the Twitter statistics for both books, and $52.6 \%$ of all Facebook comments. On Twitter the Bloggers and Reviewers group also heavily engaged, especially on The Wind Through the Keyhole as the many fan sites tweeted regularly.

Libraries saw more promise in the high quality writing and growing reputation of The Song of Achilles, and contributed 113 tweets. Booksellers, however, preferred the quick, guaranteed profits to be gained from The Wind Through the Keyhole and the 'Dark Series' readership, and created 466 tweets.

\section{The Song of Achilles}

The Song of Achilles had no established target audience, so social media marketing plans weren't seen as key to gathering sales and activity was more reactive than proactive. The team tweeted about the book and tagged Madeline Miller on their Facebook page, but the level of engagement with readers was very low. By the release of the Hardback, there were only 45 tweets on the subject of The Song of Achilles, and only two Facebook comments, both posted by the page. There were low early sales of the Hardback, with 209 in the period ending the 10th September 2011 , though this is unsurprising for a debut novel. There were modest spikes of 1,444 and 877 sales in the periods ending the 8th of October 2011 and 31st December 2011. In total, The Song of Achilles Hardback edition sold 4,499 units, far below the equivalent sales of The Wind Through the Keyhole. 
This book's marketing was content-led, as opposed to being influenced by established fans. However, once The Song of Achilles was picked on the Orange Prize longlist on the 7th March 2012, Bloomsbury began to engage more actively with Facebook and Twitter. Before the longlist announcement there had been steady activity on social media with 556 tweets and 13 comments on Facebook, but by the time of the Orange Prize victory, on the 30th May 2012, the number of tweets had risen to 1,602 and Facebook comments to 43. The link to the Orange Prize allowed Bloomsbury access to a new, marketable audience who had heard of the prize, and thus activity on both Twitter and Facebook increased enormously as Bloomsbury engaged with them. After the prize the marketing team added press reviews, images and videos of Madeline Miller, along with many posts about the book. The Orange Prize's influence, combined with the energetic response by Bloomsbury on their social media sites, dramatically affect the number of Paperbacks sold.

The Paperback edition was published on the 12th April 2012, 5 days before the Orange Prize shortlist announcement, and went on to sell 94,070 copies. The periods ending the 21st April 2012 and 19th May 2012 saw good sales of 3,102 and 10,174 respectively. However, the Orange Prize victory gave a further boost to sales, which rose to 17,519 and 19,503 in the next 2 months. These heavy sales figures, unlike with The Wind Through the Keyhole, did not instantly fall away, but lasted for several months, only falling to below 1,000 sales in April 2013. Bloomsbury's 'reactive' social media marketing strategy worked in capitalizing on the Orange Prize wave of sales and online conversation.

The social media marketing campaign for The Song of Achilles was more natural in its progression, with readers gathering around the book after recognition of the book's quality, and thus sales and social media activity grew gradually. This steady growth was not experienced in Hodder \& Stoughton's campaign. The Wind Through the Keyhole was influenced most heavily by Hodder \& Stoughton's input which appealed directly to a specific community of readers. Therefore both the social media activity and the title's sales figures consist of sharp peaks, as members of the engaged community bought the book quickly, and weren't followed by other readers. Bloomsbury offered a very interesting observation about Facebook in particular:

'The likes grew once the book won the Orange Prize implying that people engaged with the page once they knew about the book. ... there isn't really any strong commercial benefit to having people engage with the page once they have the bought the book. Having said that - this will be a useful tool if we publish a future book by the same author'.

This suggests that social media marketing, and especially Facebook, is not effective at gathering readers from scratch, and rather the real value to social media comes through its ability to converse with and exploit established communities.

Bloomsbury added more content onto their social media sites, with 52 tweets to Hodder \& Stoughton's 13, and with 42 Facebook comments to Hodder \& Stoughton's 19. Readers' reactions, particularly on Facebook, underline the difference between having a pre-existing audience and not. Hodder \& Stoughton's comments gained 3,476 likes to Bloomsbury's 970, and 1,073 re-comments to 
Bloomsbury's 145. Clearly there was an avid, active audience for Hodder \& Stoughton's comments, but interestingly this did not result in more individual comments by readers. There were 31 comments in total, with only 12 written by readers, which is tiny compared to the 100 reader posts on The Song of Achilles's wall.

The Song of Achilles benefited little from social media in its early months, but it grew into a vital platform around the Orange Prize. Also, once established, this platform can then offer a starting--point for any future campaigns with the same author.

\section{The Wind Through the Keyhole}

The huge Stephen King fan base was an influential factor in the social media campaign, and the title's sales. Given the 'mega fan' culture surrounding King and his 'Dark Tower' series, Hodder \& Stoughton had a gift-- wrapped target audience to whom they could tailor a marketing campaign. The 'StephenKingFaces' campaign, launched from Facebook, played to King's passionate fans for it allowed them to not only collect his latest offering, but also appear in it. This masterful campaign's impact was evident in both the social media reaction of 816 likes and 616 re-comments, and 21,083 sales in the month of publication.

There was considerable activity around the 'Stephen King Books' Facebook page, but it was very concentrated and focused on what the publisher offered. This could be due to the many other social media pages and sites which act as forums and conversation platforms for Stephen King's novels. Unofficial pages like 'The Dark Tower Series' on Facebook, which received 6,662 likes and 912 comments when it released The Wind Through the Keyhole cover art, may be where most of King's fans' creativity is unleashed.

Hodder \& Stoughton also used this new 'Dark Tower' title to remind readers of the series, and get them talking about it online. The first mention of the book's potential existence was on the 9th November 2009 on Twitter. From this point on Hodder \& Stoughton methodically released pieces of information about the upcoming title, including extracts and information on the 'StephenKingFaces' campaign, whetting fans' appetites right up to the publication date. This generated hype on social media, and influenced 2,457 tweets before the release of the Hardback on the 24th April 2012. This is an incredible achievement for Hodder \& Stoughton, as they resurrected conversation about a finished series, and gathered a large, active social media audience awaiting the release of the book.

The Hardback sold 34,264 copies (£384,568.13), according to Nielsen Bookscan, with an incredible 29,048 sales in the first 3 months. However, the rate of sales dropped very quickly, and by its fourth month fewer than 1,000 copies were sold a month. Clearly the excitement amongst King's committed fan base was so high that the vast majority bought books immediately, resulting in the 21,083 sales in 1 month. This highlights how effective the Hodder \& Stoughton social media campaign was at appealing to King's readership, for $38 \%$ of all sales occurred in the Hardback's first month of publication. However, there was a sharp decline in sales after the peak, suggesting that the hype around the book had not spread 
significantly to consumers outside the existing fans of Stephen King. The Paperback edition sold 21,161 copies, which in comparison to the Hardback seems disappointing. Within just six months the number of Paperback sales per month dropped to only 214 units. Clearly the success of the Hardback with the target audience negatively affected the sales of the Paperback. These results show that the campaign was not as effective at gaining new readers as it had been at stoking the excitement of King's fans. Once this community had purchased the book, the sales dropped considerably.

\section{Conclusion}

The findings have shown that social media is most effective as a marketing platform when there is already an established community, allowing publishers to converse with readers. However it is much less effective at marketing new books, written by debut authors, with no existing readership. The Song of Achilles campaign was 'reactive' because it was a debut novel, and Bloomsbury did not see it as a key, commercially beneficial avenue for the novel. However, once there was a readership established who were talking about the book and the Orange Prize award, then Bloomsbury's presence on social media became more valuable. The Wind Through the Keyhole campaign shows just how effective creative and well--targeted social media marketing can be, and its impact can be seen in the huge number of early sales after the 'StephenKingFaces' campaign. However, even in these successful circumstances social media marketing's impact is limited by the size of the specific audience being targeted. The true strength of social media in these case studies was in building and spreading hype amongst established audiences.

In these case studies, the title with less engagement from readers on social media sold more titles, because of the outside influence of the Orange Prize which could then be utilized. Clearly social media cannot be relied on alone to market books effectively, especially when such an enormous increase in sales can be influenced by these external factors. The incredible achievements of Hodder \& Stoughton's campaign in earning 34,236 Hardback sales in its first two periods, show social media marketing's potential. However, the sharp drop in sales and low number of Paperbacks sold highlight that social media marketing's reach is limited by the communities it is used to access.

Despite the crowded market social media offers a creative platform for publishers to exploit as they wish and once established, a title's social media presence can be used as a platform to exploit any future social activity that may occur. Therefore, though it may not always return a commercial benefit, social media marketing is valuable nonetheless.

If the publishing industry continues to be social, mobile and digital, social media's ability to exploit niche communities through these platforms will remain relevant. It is unlikely social media will ever be relied on solely to market books alone and should be considered as part of a broader strategy but despite this, there can be no doubt that this medium offers exciting and creative opportunities for publishers. 
Open Access This article is distributed under the terms of the Creative Commons Attribution License which permits any use, distribution, and reproduction in any medium, provided the original author(s) and the source are credited.

\section{References}

1. Nearly half of UK consumers will use smartphones this year. eMarketer. 10th June 2013. Web. 19th July 2013. http://www.emarketer.com/Article/Nearly-Half-of-UK-Consumers-Will-Use-SmartphonesThis-Year/1009956.

2. LJ interactive. Social media marketing for publishers. Oxford: LJ Interactive. 2012. Web. 15th July 2013. http://www.amazon.co.uk/Social-Media-Marketing-Publishers-ebook/dp/B007IJLGUY/ref=sr_ 1_1 ?ie=UTF8\&qid=1378075093\&sr=8-1\&keywords=ljinteractive+social+media +publishers.

3. Berger J. Contagious: why things catch on. New York: Simon \& Schuster; 2012. Bloomsbury Publishing. 16th July 2013.

4. Gladwell M. The tipping point: how little things can make a big difference. New York: Little Brown; 2002.

5. Stein B. The future of publishing will be shaped by a more dynamic social reading experience. LSE Impact of Social Sciences Blog. 8th April 2013. Web. 16th July 2013. http://blogs.lse.ac.uk/ impactofsocialsciences/2013/04/08/the-future-of-the-book-is-the-future-of-soc/.

6. The Orange Prize became the Bailey's Prize for women's fiction after a change of sponsor in 2013 .http://www.womensprizeforfiction.co.uk/title/the-song-of-achilles-3.

7. Flood A. The Wind Through the Keyhole-review". The Guardian. 18th April 2013. Web. 19th July 2013.

8. Charman--Anderson, S. “Can Nielsen Bookscan Stay Relevant in the Digital Age?". Forbes. 1st July 213. Web. 18th July 2013. http://www.forbes.com/sites/suwcharmananderson/2013/01/07/can-nielsenbookscan-stay-relevant-in-the-digital-age/. 